HENRYK JAFERNIK, JANUSZ ĆWIKLAK, KAMIL KRASUSKI

Polish Air Force Academy, Dęblin, Poland

JAROSŁAW KOZUBA

Silesian University, Katowice, Poland

\title{
APPLICATION OF IGS PRODUCTS FOR AIR NAVIGATION
}

\begin{abstract}
Single Point Positioning (SPP) method is widely used in air, marine, and land navigation to determine the user's position in real time and post factum. A typical accuracy for this method of determining the user's position in the static mode is approximately 10 meters. In air operations, the SPP method accuracy can be several times lower and that may cause problems with precise positioning of an aircraft. The authors of this article presented preliminary results of research concerning aircraft positioning in the kinematic mode based on GPS observations. For this purpose, an in-flight experiment, in which a Cessna 172 aircraft was used, was performed at the airport in Mielec, Poland. The aircraft was equipped with a dual-frequency Topcon TPS HiperPro receiver, which was recording satellite observations with 1-second interval. The aircraft position was determined using the leastsquares method (LSM) in the RTKLIB (RTKPOST module) software. Two research tests were performed within the scope of the experiment, i.e. in test I the aircraft position was determined on the basis of raw GPS observations and the broadcast ephemeris data whereas in test II precision products of the IGS were used, such as: precise ephemeris SP3, DCB hardware delay, clock bias data of GPS satellites and receivers in the CLK format, data of the ionosphere maps based on IONEX format, and phase center calibration of GPS satellites and receivers in the ANTEX format. The use of the IGS precision products improved the accuracy of the $X$ coordinate to $1 \mathrm{~m}, Y$ to $0.7 \mathrm{~m}$ and $Z$ to $1.3 \mathrm{~m}$. On the basis of tests I and II, an additional RMS-3D parameter was determined, whose mean value was $4 \mathrm{~m}$.
\end{abstract}

\section{Keywords:}

GPS, IGS, SPP method, positioning accuracy, air navigation. 


\section{INTRODUCTION}

One of the methods most commonly used in navigation (land, marine and air) to determine the user's position is Single Point Positioning absolute method. The concept of the SPP method is based on synchronously observing at least of 4 GPS satellites by a satellite antenna-receiver antenna system. Measurements (code observations) are a major source and research material in the process of defining the user's coordinates at any time of the day, anywhere on the Earth. The code observations are divided into two fundamental types, observations using the precision code $(\mathrm{P})$ and observations using the C/A code, which is freely accessible. Observations with the code $\mathrm{P}$ are broadcast by GPS satellites at both carrier frequencies, L1 (1575.42 MHz) and L2 (1227.60 MHz). The mean accuracy of GPS code observations ranges from $30 \mathrm{~cm}$ to $3 \mathrm{~m}$, assuming that the speed of light is $299792458 \mathrm{~m} / \mathrm{s}$ [Dach et al., 2007; Schaer, 1999]. Until 2000, the use of GPS observations for civilian users had technological constraints due to the inclusion of the intentional degradation procedure of satellite clock corrections, and the position of the satellite in the orbit (Selective Availability, SA), as well as the replacement of the precise $\mathrm{P}$ code with the military code, Y (Anti-Spoofing AS), the accuracy of which is lower than $1 \mathrm{~m}$. While the intentional signal degradation procedure, SA, has been fully disabled, P-code receivers are still subject to signal degradation AS [de Jonge, 1998]. In the 1990s, attempts at repairing the precision code $\mathrm{P}$ by numerous manufacturers of satellite receivers involved huge financial costs but the quality of the solution was unsatisfactory. Currently, a fairly common technique used to reproduce the $\mathrm{P}$ code is the $\mathrm{Z}$-tracking technique (passing correlated $\mathrm{P}$ code replica from the receiver and code $\mathrm{Y}$ through the low-pass filter at both carrier frequencies L1 and L2) [Hofmann-Wellenhof, Lichtenegger, Wasle, 2008].

Impediments and problems with the implementation of $\mathrm{P}$ code in the navigation positioning process enabled the spread of $\mathrm{C} / \mathrm{A}$ code in the numerical calculations of satellite observations. C/A code is transmitted at carrier frequencies L1, L2, and L5, and its standard accuracy varies from 3 to $30 \mathrm{~m}$. Code C/A observations are burdened with higher measurement noise in relation to the P-code and contain many systematic errors, such as: atmospheric corrections (ionospheric and tropospheric), satellite clock bias, relativistic satellite clock correction, and DCB hardware delay for satellites and the receiver. Furthermore, pseudoranges include geometric factors, i.e. Sagnac effect, errors of determining the coordinates of the satellite in the orbit, 
change of the phase center of the satellite and the receiver, the effect of Earth's rotation, and the precision and accuracy of the user's initial coordinates [Spits, 2011; Sanz Subirana, Juan Zornoza, Hernández-Pajares, 2013; Zhang, 2007]. Typical accuracy for position determination with C/A code observations is approximately $10 \mathrm{~m}$ with a probability of $95 \%$ [Kaplan, Hegarty, 2006]. The use of the IGS precision products can reduce or eliminate to a large extent the impact of certain systematic and geometric errors. The main precision products of the IGS are, among others [Kouba, 2009]:

- precise ephemerides with the coordinates of satellites in the '*.SP3' or ‘*.EPH' format;

- characteristics of the satellite and the receiver antennas in the 'ANTEX' format;

- precision satellite and receiver clock bias corrections in the '*.CLK' format;

- Earth's rotation parameters in the '*.ERP' format;

- VTEC ionosphere parameters written in the 'IONEX' format;

- ZTD troposphere parameters written in the 'SNX_TRO' format;

- DCB hardware delay for satellites and receivers in the '*.DCB' format.

The online access to the precision products of the IGS is free of charge for all users, on the website [16]. The process of creating final IGS products arises from the combination of individual solutions at Local Analysis Centers (LAC). A scheme of combining the solutions is usually based on a weighted average algorithm, with additional determination of the mean error parameter for the resultant value of a given product.

The primary purpose of the use of the IGS products is to improve the precision of determining the user's position and to increase the accuracy to $1 \mathrm{~m}$ (or better) for the SPP method. This article presents the problem of determining the coordinates of the user's position with and without the use of the IGS service precision products. The calculations were made using the least-squares method (LSM) in the RTKLIB (RTKPOST module) software. The raw GPS observations were taken from a Topcon TPS HiperPro dual frequency receiver mounted onboard a Cessna 172 aircraft. The results obtained in the research conducted have been presented in the appropriate graphic charts. 


\section{RESEARCH METHODOLOGY}

Section 2 of the article presents a detailed description of the research method used in the experiment (Single Point Positioning method) together with the calculation algorithm. It contains the presentation and characteristics of systematic errors used in the process of determining the position for the SPP method. Furthermore, it presents a mathematical model of positioning for the SPP method.

\section{SPP Method}

In the process of determining the user's position, basic observational equation was used for the absolute point positioning method [Aragon-Angel, 2010]:

$$
p=d+c \cdot\left(d t_{0}-d t_{S}\right)+\operatorname{Ion}+\operatorname{Trop}+\operatorname{Rel}+\mathrm{DCB}
$$

where:

$p$

— code measurement of the C/A (pseudorange) at the first frequency in the GPS system, the value given in the [1 m] unit,

$d \quad$ - geometric distance between the satellite and the receiver antennas, the value given in the $[1 \mathrm{~m}]$ unit

$$
d=\left\{\left(x-X_{S}\right)^{2}+\left(y-Y_{S}\right)^{2}+\left(z-Z_{S}\right)^{2}\right\}^{0,5},
$$

$(x, y, z) \quad$ - aircraft position in $X Y Z$ coordinates,

$\left(X_{S}, Y_{S}, Z_{S}\right)$ - satellite coordinates,

c - speed of light, the value given in the $[1 \mathrm{~m} / \mathrm{s}]$ unit,

$d t_{0} \quad$ - receiver clock bias correction, the value given in the [1 s] unit,

$d t_{S} \quad$ - satellite clock bias correction, the value given in the [1 s] unit,

Ion - ionospheric correction, the value given in the [1 $\mathrm{m}]$ unit,

Trop - tropospheric correction, the value given in the [1 m] unit,

Rel - relativistic correction, the value given in the [1 m] unit,

DCB - total value of hardware delays for GPS satellites and the receiver, the value given in the $[1 \mathrm{~m}]$ unit DCB = SDCB + RDCB [Krasuski, 2015],

SDCB - Satellite DCB,

RDCB - Receiver DCB. 


\section{Aircraft positioning process}

First, in the process of aircraft position determination the parameters from equation (1) must be separated from the unknown parameters:

$$
p+c \cdot d t_{S}-\text { Ion }- \text { Trop }-\operatorname{Rel}-\mathrm{DCB}=d+c \cdot d t_{0} .
$$

If the geometric distance, the parameter from equation (1) is expressed by the coordinates of the antenna and the satellite, the observation equation is development using Taylor series to the form:

$$
1=(\Delta x / d) \cdot \delta x+(\Delta y / d) \cdot \delta y+(\Delta z / d) \cdot \delta z+c \cdot d t_{0},
$$

where:

$\Delta x=x-X_{S}$,

$\Delta y=y-Y_{S}$,

$\Delta z=z-Z_{S}$,

$1=p+c \cdot d t_{S}-$ Ion - Trop - Rel $-\mathrm{DCB}-d$.

Written as a matrix, the equation (3) is [Grewal, Weill, Andrews, 2001]:

$$
A \cdot \Delta r-l=v,
$$

where:

$A$ - coefficient matrix,

$\Delta r$ - vector of parameters determined,

$l$ - vector of free terms;

$v$ - vector of residuals.

In the SPP method, the unknown parameters from equation (3) are determined by the least-squares iterative process [Petrovski, 2014]:

$$
\Delta r=\left(A^{T} \cdot P \cdot A\right)^{-1} \cdot A^{T} \cdot P \cdot l
$$

where:

$P \quad$ - matrix of observation weights, $P=\left(m_{0}^{2} / m_{l}^{2}\right)$,

$m_{0}^{2}$ - unitary variance a priori, $m_{0}=1$,

$m_{l}$ - standard deviation of pseudorange, $m_{l}=c_{X} / \sin (E l)$,

$c_{X}$ - accuracy of C/A code observations,

$\mathrm{El}$ - angle of elevation. 
Standard deviation of the parameters determined is described by the relationship [Hofmann-Wellenhof, Lichtenegger, Wasle, 2008]:

$$
M x=\operatorname{diag}\left(\left(\delta_{0}^{2} \cdot N^{-1}\right)^{0,5}\right)=[Q x Q y Q z Q d t o]^{T},
$$

where:

diag - diagonal values of the variance-covariance matrix $\left(\delta_{0}^{2} \cdot N^{-1}\right)$,

$\delta_{0}{ }^{2}$ - unitary variance a posteriori $\delta_{0}=\left(\left[v^{T} \cdot P \cdot v\right] /(n-k)\right)^{0,5}$

$n$ - number of observations in a measurement epoch,

$k \quad$ - number of parameters determined in a measurement epoch, $k=4$,

$N^{-1} \quad$ - cofactor matrix, $N^{-1}=\left(A^{T} \cdot P \cdot A\right)^{-1}$,

$Q x \quad$ - standard deviation of $X$ coordinate,

Qy - standard deviation of $Y$ coordinate,

$Q z \quad$ - standard deviation of $Z$ coordinate,

Qdto - standard deviation of the receiver clock bias.

\section{EXPERIMENT AND DISCUSSION OF RESULTS}

Section 3 of the article presents the results of the research conducted within the framework of the in-flight experiment in the Mielec airport. It shows the configuration of the parameters used in the calculations, and presents the preliminary results of aircraft positioning accuracy for geodesic coordinates BLh. The calculations were made using the RTKLIB (RTKPOST module) software.

\section{Description of experiment}

The experiments were performed using raw GPS data obtained from a dual frequency Topcon TPS HiperPro receiver mounted onboard a Cessna 172 aircraft. The research experiment was conducted on September 07, 2011 near the city of Mielec, Poland. The test flight lasted 58 minutes 57 seconds according to the GPST time, and the receiver recorded the GPS observations with 1-second interval. It is worth noting that the Topcon TPS HiperPro receiver was also collecting the GLONASS observations. The GPS observations collected and saved in the receiver's memory were used for the determination of the Cessna's position and recreating the flight 
trajectory. The calculations were performed using the commercially available RTKLIB software with the RTKPOST module [18]. The following parameters were set in the RTKPOST module for the determination of the coordinates and obtaining the proper accuracy:

- RINEX data format: 2.11;

- source of ephemeral data: GPS navigation message and precise ephemeris (file downloaded from the website [16]);

- GPS satellite positioning method: on the basis of the Keplerian orbital parameters and the Lagrange polynomial;

- pseudorange correction from the satellite to the receiver antenna: applied;

- effect of Earth's rotation: applied;

- Sagnac effect: applied;

- tidal effects, pole movement, pressure of the atmosphere and ocean: neglected;

- satellite clock data source: GPS navigation message and precise ephemeris;

- method of determining satellite clock bias: second order interpolation polynomial and Lagrange polynomial;

- relativistic effects: applied;

- TGD hardware delay: applied, on the basis of GPS navigation message;

- DCB P1-P2 hardware delay: applied, on the basis of the DCB P1-P2 file from the CODE Analysis Center in Switzerland [15];

- DCB P1-C1 hardware delay: applied, on the basis of the DCB P1-C1 file from the CODE Analysis Center in Switzerland [15];

- multipath effect - neglected;

- troposphere model: Saastamoinen;

- ionosphere model: Klobuchar and global ionosphere model in the IONEX format;

- VTEC ionosphere maps: on the basis of the IONEX file from the IGS (file downloaded from the website [14]);

- GPS satellite antenna phase center correction: applied on the basis of the ANTEX file from the CODE Analysis Center in Switzerland;

- receiver antenna phase center correction: applied on the basis of the ANTEX file from the CODE Analysis Center in Switzerland;

- positioning type: Single;

- positioning mode: kinematic; 
- observation type: code C1 observations;

- positioning method: least — squares method (LSM);

- observation weighting: yes;

- observation mask angle: $10^{0}$;

- reference frame: geocentric ECEF (IGS08);

- number of observations: $n>4$;

- number of parameters being determined $k=4$;

- approximate coordinates of the aircraft position: based on the RINEX file;

- coordinate format: $X Y Z$ coordinates in the geocentric format;

- receiver clock bias: determined.

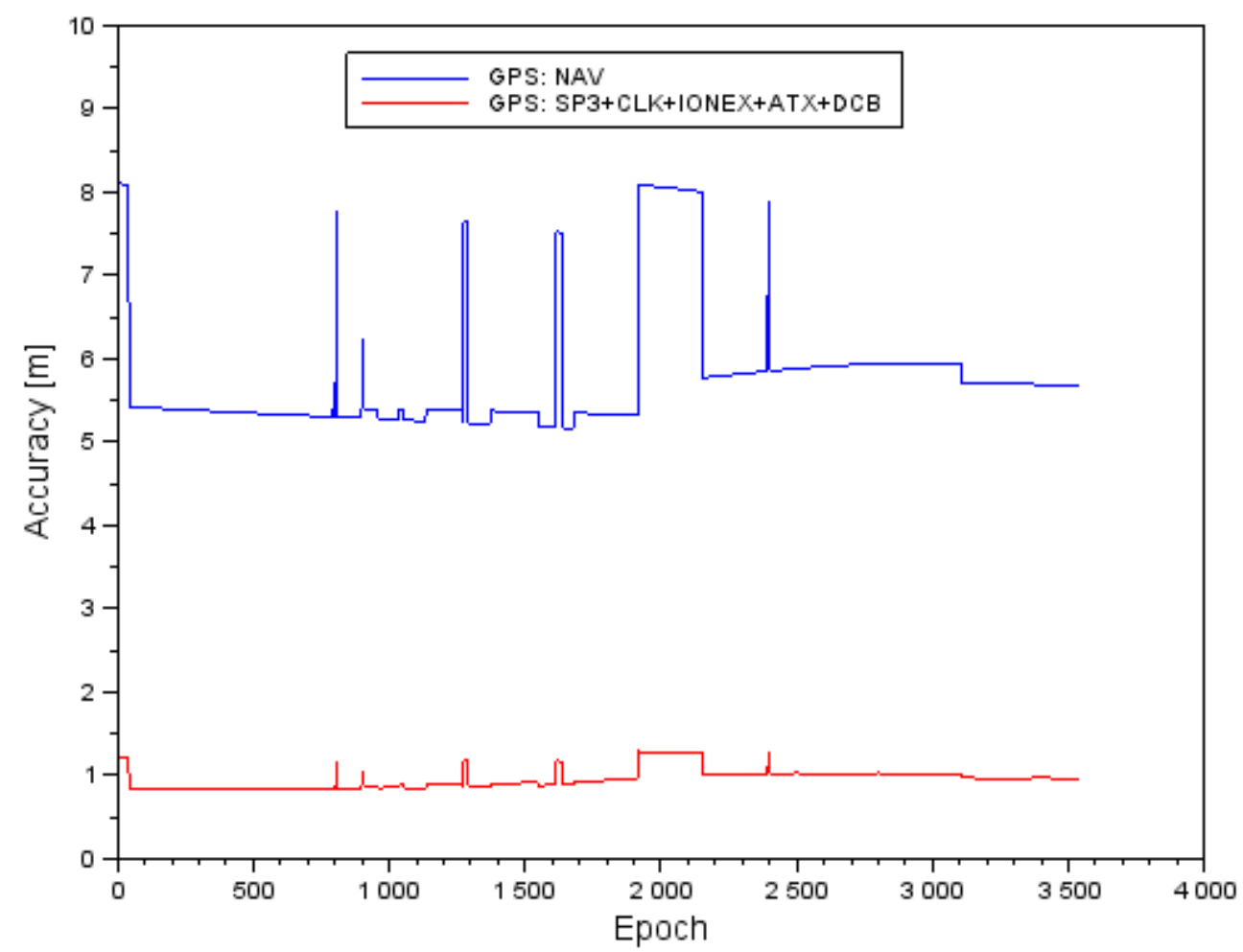

Fig. 1. Standard deviation of $X$ coordinate 


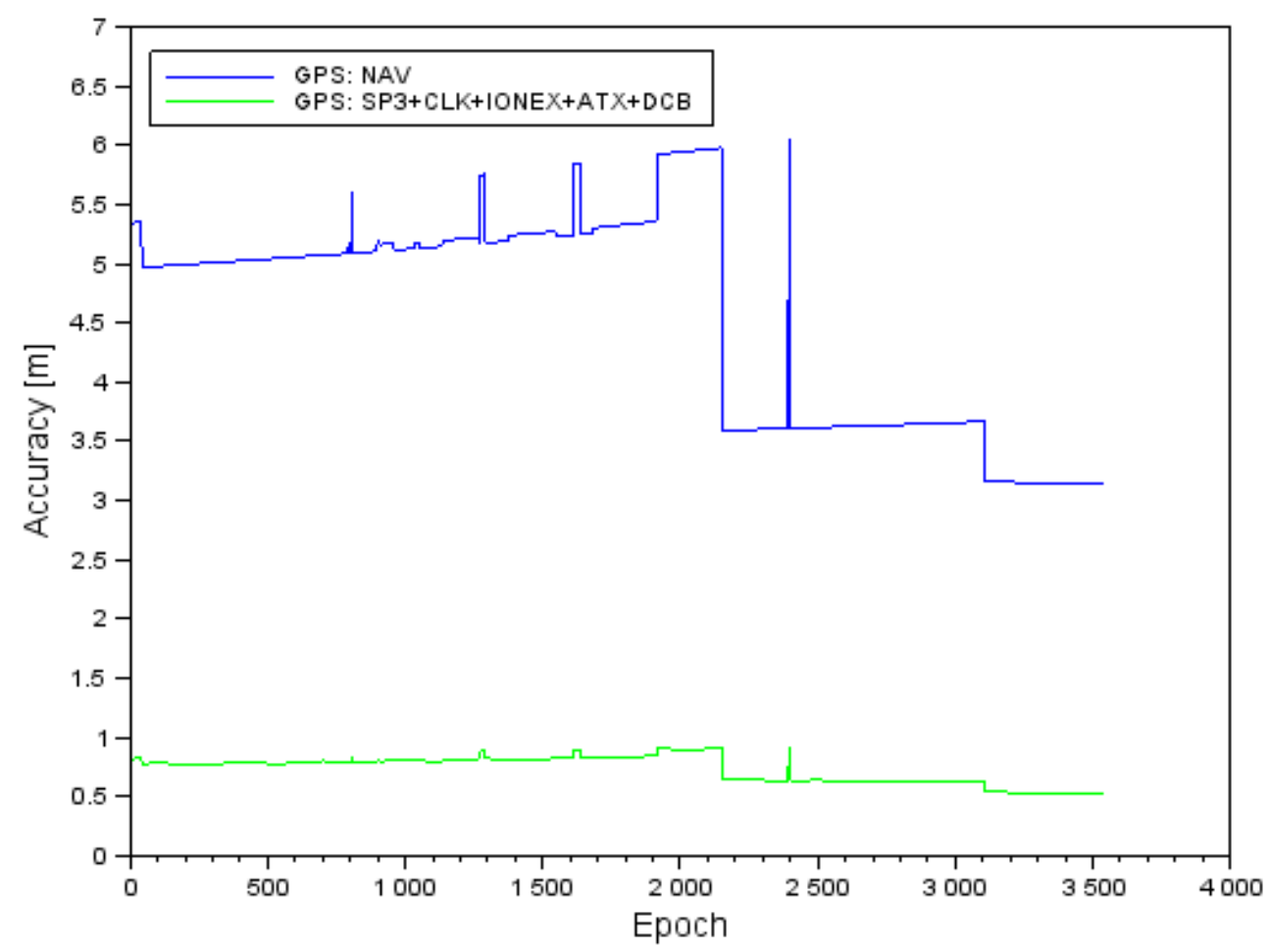

Fig. 2. Standard deviation of $Y$ coordinate

\section{Accuracy analysis of aircraft positioning}

The studies conducted comprised two numerical tests, i.e. in test I aircraft position was determined only on the basis of raw GPS observations and the data from broadcast ephemeris, while in test II the information used came from the SP3 precise ephemeris, the IONEX, CLK, DCB, and ANTEX format.

Figure 1 shows the standard deviations $Q x$ of the $X$ coordinate from solutions I (blue) and II (red) for each measurement epoch. The mean errors of the $X$ coordinate obtained in test I are considerably higher than those obtained in test II. The mean error dispersion for test $\mathrm{I}$ is from $5 \mathrm{~m}$ to $9 \mathrm{~m}$. In test II, the limits are $0.8 \mathrm{~m}$ and $1.3 \mathrm{~m}$, respectively. The mean standard deviation value for the $X$ coordinate in test II is less than $1 \mathrm{~m}$, while in test I more than $5.7 \mathrm{~m}$. The outstanding points in Figure 1 (change of coordinate $X$ accuracy) are most noticeable in the middle phase of the Cessna flight. 
Figure 2 shows the standard deviations $Q y$ of the $Y$ coordinate from solutions I (blue) and II (green). In analogy to Figure 1, the results for the $Y$ coordinate accuracy were improved in test II. As regards test I, the mean error values of the $Y$ coordinate ranges from $3 \mathrm{~m}$ to almost; $7 \mathrm{~m}$. The same dispersion for test II is from $0.5 \mathrm{~m}$ to $1 \mathrm{~m}$. It is worth mentioning that the final accuracy of the $Y$ coordinate is better than that of the $\mathrm{X}$ coordinate. The mean standard deviation value for the $Y$ coordinate in test II is over $0.7 \mathrm{~m}$, whereas in test I more than $4.5 \mathrm{~m}$.

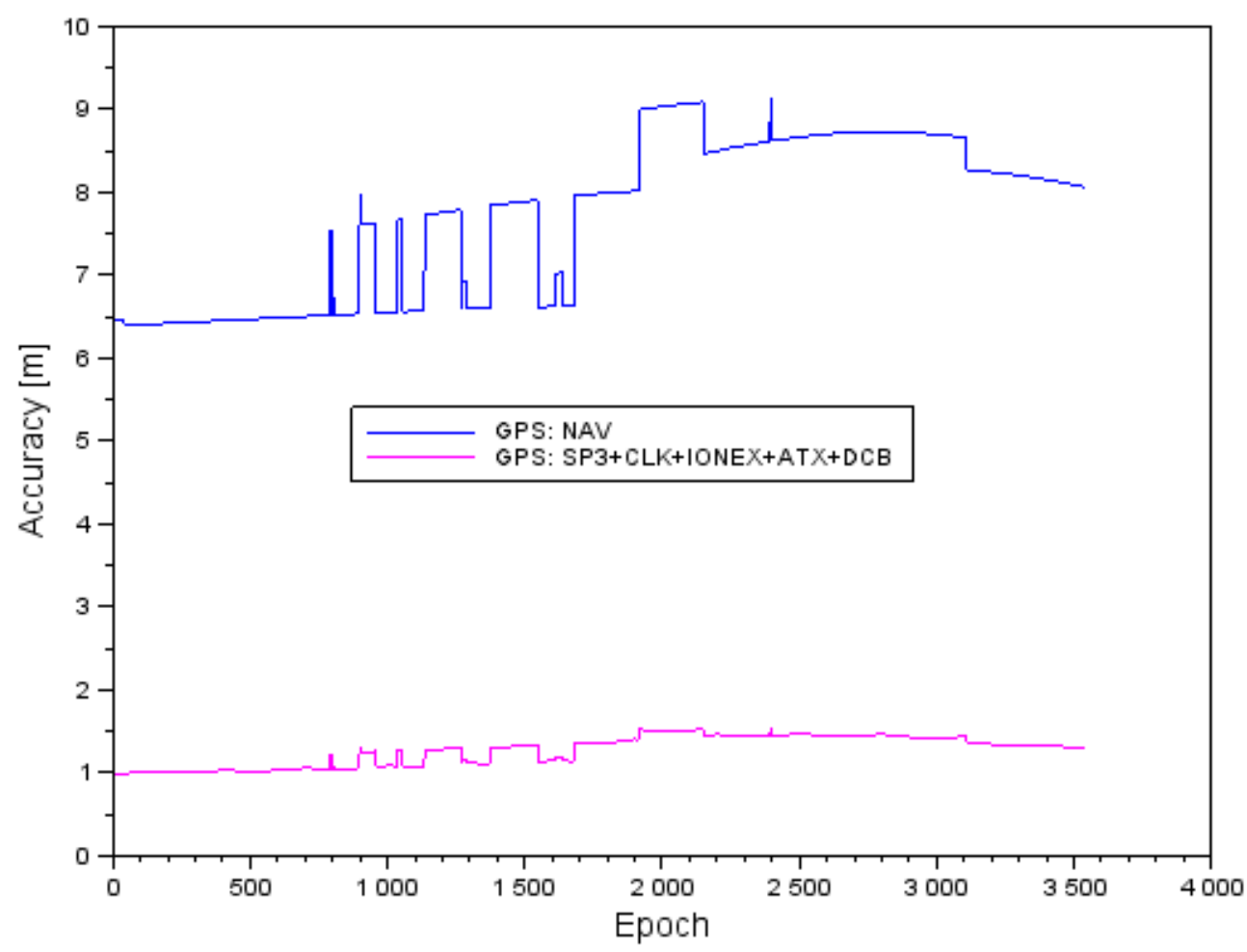

Fig. 3. Standard deviation of $Z$ coordinate

Figure 3 shows the standard deviations $Q z$ of the $Z$ coordinate from solutions I (blue) and II (red) for each measurement epoch. The mean errors obtained from the calculations are, like in graph 1 and 2, better for test II. The dispersion of $Q z$ term for test I is from $6.4 \mathrm{~m}$ to $9 \mathrm{~m}$. In test II, the limits are $1 \mathrm{~m}$ and $1.5 \mathrm{~m}$, respectively. The mean standard deviation value for the $\mathrm{Z}$ coordinate in test II is less than $1.3 \mathrm{~m}$, while in test I more than $7.7 \mathrm{~m}$. In comparison with the results in graphs 1 and 2, the mean error accuracy for the $Z$ coordinate strongly deteriorated. 
In Figure 3 the changes of the $Z$ coordinate accuracy are most noticeable in the middle phase of the Cessna flight. It is worth noting that in the final measurement epochs the $Z$ coordinate accuracy is improved, as well as that of $X$ and $Y$.

Based on the data from charts 1, 2 and 3, a conclusion can be drawn that the use of the IGS precision products in air navigation can effectively eliminate or reduce a number of systematic errors in the process of the development of GPS observations in the kinematic mode, and thus increase the accuracy of aircraft positioning. The aspect of improving the aircraft positioning accuracy is critical to increase passenger transport safety, civilian and military. The use of standard models and computational strategies based largely on the parameters of physical and instrumental phenomena, included in the GPS broadcast navigation message, cause large errors in the aircraft position (see Fig. 1-3). On the other hand, the presented computational strategy for test no. II applies only to the processing of measurement results in the post-processing mode. However, the IGS already distributes precision products predicted a few days ahead. Position and clock corrections of GPS satellites are already estimated 120 hours (5 days) ahead and they are distributed in the format of precision ephemeris 'EPH' by the CODE Analysis Center in Switzerland $[15,17]$. Furthermore, the SDCB hardware delays can be assumed constant on a monthly basis. VTEC maps of the ionosphere in the IONEX format are already predicted 48 hours ahead by the CODE and they ensure better accuracy than the description of the ionosphere state given by the Klobuchar model. The troposphere parameters (ZTD, ZWD, and ZHD) can be determined on an ongoing basis by using data from weather sensors installed onboard the aircraft. The parameters of the GPS satellite antenna phase centres are stored in the ANTEX format and made available on the IGS website or on local LAC servers. The receiver antenna phase centre is determined for each series of receivers prior to its launch on the market and saved in the ANTEX format.

The computational strategy in test II, presented by the authors may soon become an essential part of the FMS calculation module within the onboard computer. Obviously, the most important element resting on the aircrew, will remain the appropriate selection of input data and the configuration of the FMS calculation module parameters. Therefore, there is the need for training and exercises for aircrews to understand the aircraft positioning mechanism based on test II.

The RMS-3D error parameter was also calculated within the precision of determining geocentric coordinates $X Y Z$ from test I and II:

$$
\text { RMS-3D }=\left(D X^{2}+D Y^{2}+D Z^{2}\right)^{0,5},
$$


where:

$D X=X_{\mathrm{II}}-X_{\mathrm{I}}$, difference between $X$ coordinate for test I and II,

$D Z=Y_{\mathrm{II}}-Y_{\mathrm{I}}$, difference between $Y$ coordinate for test I and II,

$D Z=Z_{\mathrm{II}}-Z_{\mathrm{I}}$, difference between $Z$ coordinate for test I and II.

In Figure 4, the values of the RMS-3D parameter obtained from test I and II were presented against the number of visible satellites. The mean value of RMS-3D error amounted to more than $4 \mathrm{~m}$ for a numerical range from $3.7 \mathrm{~m}$ to $6.7 \mathrm{~m}$. It should be noted that the number of satellites visible above the horizon for the results of the RMS-3D error obtained ranges from 6 to 8 . Only 27\% of the parameter RMS-3D results are less than $4 \mathrm{~m}$, and almost $88 \%$ less than $4.5 \mathrm{~m}$.

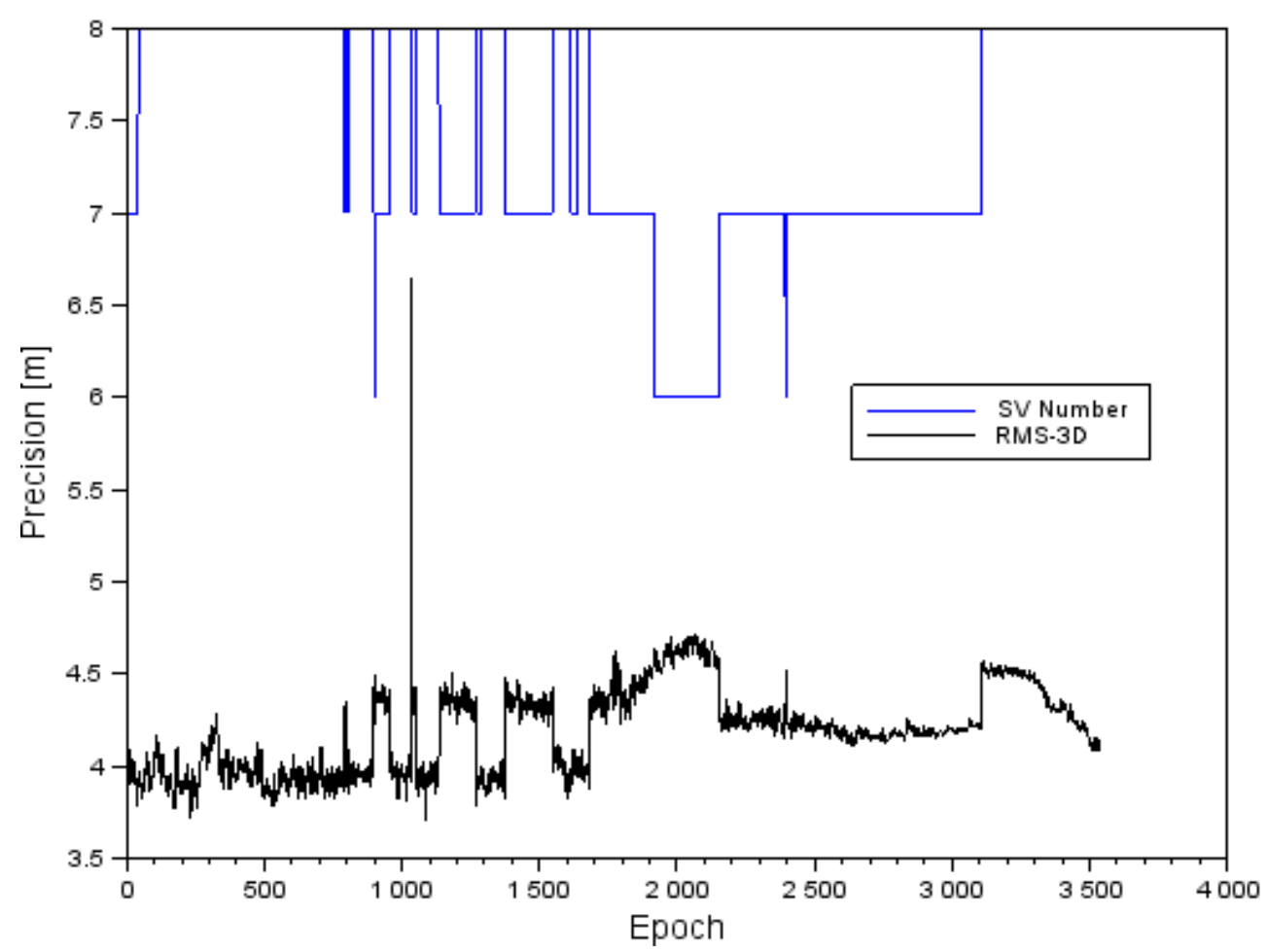

Fig. 4. RMS-3D error of the aircraft coordinates 


\section{CONCLUSIONS}

The article presents the possibility of using precise IGS service products to improve the aircraft positioning. To this end, two research experiments were performed in which aircraft coordinates were determined using the SPP method based on broadcast ephemeris (test I), and SP3 precise ephemeris in the CLK, IONEX, DCB, and ANTEX formats (test II). The experiments were performed for raw GPS data (with 1 second interval) obtained using a dual frequency Topcon TPS HiperPro receiver mounted onboard a Cessna 172 aircraft. The test flight was performed on September 07, 2011. The calculations were made in the RTKLIB (RTKPOST module) software using the least-squares method (LSM). The positioning accuracy results presented in the article underline the argument that the use of the IGS products in GPS kinematic positioning considerably improves the standard deviation of the coordinates determined to approximately $1 \mathrm{~m}$. It is worth noting that the use of the IGS products affected precision of the XYZ coordinates in such a way that the average value of the RMS-3D error was greater than 4 meters based on test I and II.

The original research results presented in this paper only concern the application of precise IGS products in air navigation in the post-processing mode. The use of IGS products in real time air navigation is very limited. This involves the construction of a special telecommunication and information infrastructure on board an aircraft and, above all, maintaining the continuity of the Internet connection with network data from the IGS product database. In addition, an appropriate input configuration of the FMS onboard computer with IGS data is also essential. One possible solution to the above-mentioned problems would be to use the IGS 'prediction type' products for navigation computations. In such a way, it would be possible to specify satellite coordinates in the 'SP3/EPH' format and corrections of satellite clocks in the 'CLK' format. Moreover, the use of 'prediction-type' IGS products would allow the continuity of ephemeris data in the event of a failure or lack of data from the GNSS navigation system in near real time. However, the 'prediction-type' IGS products should be, additionally compared with the 'final-type' products in order to verify their quality, accuracy and reliability of data. In the future, the authors also plan to use IGS products to determine the coordinates of aircraft in air navigation for the precise positioning method PPP. 


\section{Acknowledgements}

The authors of this article wish to thank IGS for providing precise ephemerides and GPS satellite clock data and Mr Tomoji Takasu for allowing the use of RTKLIB libraries [18].

\section{REFERENCES}

[1] Aragon-Angel A., Contributions to ionospheric electron density retrieval, Ph.D. thesis, UPC, Spain, 2010.

[2] Dach R., Hugentobler U., Fridez P., Meindl M., Bernese GPS software version 5.0, Astronomical Institute, University of Bern, 2007.

[3] De Jonge P. J., A processing strategy for the application of the GPS in networks, Publications on Geodesy 46, Delf 1998.

[4] Grewal M. S., Weill L. R., Andrews A. P., Global Positioning Systems, Inertial Navigation and Integration, A John Wiley \& Sons, Inc. Publication, New York 2001.

[5] Hofmann-Wellenhof B., Lichtenegger H., Wasle E., GNSS - Global Navigation Satellite Systems: GPS, GLONASS, Galileo and more, Springer Wien-NewYork, Wien 2008.

[6] Kaplan E. D., Hegarty C. J., Understanding GPS: Principles and Applications, 2nd edition, Artech House, INC, Norwood, USA, 2006.

[7] Kouba J., A guide to using INTERNATIONAL GNSS SERVICE (IGS) Products, 2009, [online], http://acc.igs.org/UsingIGSProductsVer21.pdf [access 01.06.2016].

[8] Krasuski K., Utilization instrumental biases DCB for positioning correction over Ryki District, 'Przegląd Telekomunikacyjny', 2015, No. 7, pp. 659-663, DOI: 10.15199/59.2015.7.3.

[9] Petrovski I. G., GPS, GLONASS, Galileo, and BeiDou for Mobile Devices, Published in the United States of America by Cambridge University Press, New York 2014.

[10] Sanz Subirana J., Juan Zornoza J. M., Hernández-Pajares M., GNSS Data Processing, Volume I: Fundamentals and Algorithms, Publisher: ESA Communications, ESTEC, Noordwijk, Netherlands, ISBN: 978-92-9221-886-7, 2013.

[11] Schaer S., Mapping and predicting the Earth's ionosphere using the Global Positioning System, Ph. D. thesis, Switzerland 1999.

[12] Spits J., Total Electron Content reconstruction using triple frequency GNSS signals, $\mathrm{PhD}$ thesis, Universitè de Liège, Belgium, 2011.

[13] Zhang J., Precise velocity and acceleration determination using a standalone GPS receiver in real time, Dissertation thesis, Royal Melbourne Institute of Technology, Australia, 2007.

[14] ftp://cddis.nasa.gov/pub/gps/products/ionex/2011 [access 01.06.2016].

[15] ftp://ftp.unibe.ch/aiub/CODE/2011 [access 01.06.2016]. 
[16] ftp://igscb.jpl.nasa.gov/igscb/product/ [access 01.06.2016].

[17] http://www.bernese.unibe.ch/download/ [access 01.06.2016].

[18] www.rtklib.com [access 01.06.2016].

Received October 2016

Reviewed July 2017

Published 09.01.2018

\section{HENRYK JAFERNIK}

Polish Air Force Academy

Dywizjonu 303, 35 Str., 08-521 Dęblin, Poland

e-mail: henryk21@interia.pl

\section{JANUSZ ĆWIKLAK}

Polish Air Force Academy

Dywizjonu 303, 35 Str., 08-521 Dęblin, Poland

e-mail: jcwiklak@wp.pl

\section{KAMIL KRASUSKI}

Polish Air Force Academy

Dywizjonu 303, 35 Str., 08-521 Dęblin, Poland e-mail: kk_deblin@wp.pl

\section{JAROSŁAW KOZUBA}

Silesian University

Krasińskiego 8 Str., 40-019 Katowice, Poland

e-mail: aabuzok@wp.pl

\section{STRESZCZENIE}

Metoda pozycjonowania w czasie rzeczywistym, nazywana Single Point Positioning, jest powszechnie stosowana w nawigacji lotniczej, morskiej, a także lądowej do określania pozycji użytkownika w czasie rzeczywistym, niekiedy również post-processing. Zwykle dokładność metody w przypadku użytkownika, który nie przemieszcza się, oceniana jest na około 10 metrów. W operacjach lotniczych jej dokładność bywa wielokrotnie niższa, co często stwarza problemy. Autorzy artykułu przedstawiają wstępne wyniki badań odnośnie dokładności pozycjonowania samolotu w wariancie dynamicznym z wykorzystaniem systemu GPS. W tym celu na lotnisku Mielec przeprowadzono eksperyment w locie z użyciem samolotu Cessna 172, który wyposażono w dwuczęstotliwościowy odbiornik Topcon TPS HiperPro rejestrujący obserwacje co sekundę. Jako pozycje referencyjne przyjęto pozycje obliczane metodą najmniejszych kwadratów programem RTKLIB (moduł RTKPOST). $\mathrm{W}$ ramach opisywanego eksperymentu przeprowadzono dwa testy — w pierwszym określano 
pozycje z użyciem surowych pomiarów GPS oraz efemeryd pokładowych, w drugim użyto efemeryd oferowanych przez IGS. Były to takie dane, jak efemerydy precyzyjne SP3, poprawki zegarów satelitów w formacie CLK, mapy jonosfery w formacie IONEX oraz dane odnośnie centrum fazowego anten w formacie ANTEX.

Użycie produktów oferowanych przez IGS znacząco poprawiło dokładność wyznaczeń, przy czym współrzędna $X$ została wyznaczona z dokładnością $1 \mathrm{~m}$, współrzędna $Y-0,7 \mathrm{~m}$, natomiast $Z-1,3 \mathrm{~m}$. Dodatkowo wyznaczono średni błąd pozycji w przestrzeni 3D, którego wartość wyniosła około $4 \mathrm{~m}$. 